\title{
The Effect of Job Satisfaction and Work Motivation on Turnover Intention through Organizational Commitment in PT. Bank BPD Banten, TBK Operational Center Office of Serang
}

\author{
Halmatus Sa'diah Lubis ${ }^{1}$, Tantri Yanuar R. Syah ${ }^{2}$ \\ Esa Unggul University Jakarta
}

\begin{abstract}
The purpose of research is to determine the effect of Job Satisfaction (X1) and Work Motivation (X2) to Turnover Intention (Y2) through Organizational Commitment (Y1) on PT. BPD Banten Bank, Tbk Operational Headquarters Office. This research was conducted to employees of PT. Bank BPD Banten, Tbk with a total of 195 respondents. The subsequent purpose is to find correlation between variables and the covariance measurement tested by using Structural Equation Modelling Method (SEM). The results indicate that Job Satisfaction has a positive and significant effect on Organizational Commitment, Job Motivation has a positive and significant effect on Organizational Commitment, Job Satisfaction has no effect on Turnover Intention, Job Motivation has no effect on Turnover Intention, Organizational Commitment has no effect on Turnover Intention.
\end{abstract}

Keywords: Job Satisfaction, Work Motivation, Organizational Commitment, Turnover Intention

\section{INTRODUCTION}

Bank Banten is one of the companies that has crisis issues in internal HR management in 2015 and has acquired in 2016. at first time, Banten Bank was established as PT Executive International Bank which began operation as a commercial bank in Jakarta on August 9, 1993. Then, the Company was renamed to PT. Bank Pundi Indonesia, Tbk on June 30, 2004. However in the third quarter of 2010, PT. Bank Pundi Indonesia, Tbk suffered a loss of Rp 230.22 billion In addition, fee based income as of September 2010 was down 39.03\% from Rp 58.132 billion to Rp 35.444 billion. The profit from the sale of fixed assets and investment of Rp 82 million was not able to help the performance of Bank Pundi. Finally, the company recorded a net loss of Rp 230.22 billion. On the other hand, NPL at Bank Pundi has reached 51.33\%. While, Regulation of Bank Indonesia No. 17/11 / PBI / 2015 states that the limit of NPL is 5\%. This value is too far from the safe limit of the NPL and its shows that Bank Pundi has a very high level of bad credit. This shows the performance of Bank Pundi has declined considerably.

Internal problems in PT. Bank Pundi Indonesia, Tbk continued, then in 2015, 4 functionary of bank pundi arrested for for entangled corruption. This issue caused Bank Pundi shares to decrease by $8.47 \%$. Finally in 2016, PT. Bank Pundi Indonesia, Tbk was acquired by the Banten Provincial Government through PT. Banten Global Development. In accordance with the Decision of the Board of Commissioners of the Financial Services Authority No: 12 / KDK.03 / 2016 concerning the Determination of the Use of Business Licenses on behalf of PT. Bank Pundi Indonesia, Tbk. become a Business License on behalf of PT. Bank BPD Banten, Tbk. The company is officially operated as PT. Bank BPD Banten, Tbk on July 29, 2016. There are still many internal problems that have not been resolved, the policy taken by the company is to reduce the amount of employees and branch offices to improve the efficiency. The amount of Employee and branch office reduction data can be seen in the table below:

Table 1. Data on Number of Offices and Number of Employees of PT. Bank BPD Banten, Tbk

\begin{tabular}{|c|c|c|}
\hline Year & Office & Employees \\
\hline $\mathbf{2 0 1 4}$ & 187 & 7291 \\
\hline $\mathbf{2 0 1 5}$ & 136 & 4341 \\
\hline $\mathbf{2 0 1 6}$ & 104 & 2776 \\
\hline
\end{tabular}

Source: (http://www.bankbanten.co.id, November 17, 2017) 


\section{International Advanced Research Journal in Science, Engineering and Technology}

Vol. 6, Issue 5, May 2019

This data present that transition from Bank Pundi to Bank Banten as decrease the amount of employees and branch offices. The organizational restructuring occurred on a large scale when the transition of Bank Pundi to Bank Banten. Many potential and domiciled employees outside Banten Province are transferred to Banten Province, but many of them are not willing to be assigned to places that are not their origin. In addition, many employees who quit because it is done termination in order to increase the efficiency of the company in the transition period. So that the number of employees drastically decreased. The newly established Bank Banten need to retain their employees, especially with the potential employees to assist in expansion activities. Therefore, it is crucial for the Bank Banten to determine the level of turnover intention and the things that affect the rate of turnover intention. According to the result of research by Youcef et al. (2016) show that job satisfaction and organizational commitment has effect on turnover intention. In addition, research from Rumlall et al. (2011) show that work motivation and organizational commitment has effect on turnover intention.

To determine the condition of Bank Banten employees, a pre-survey was conducted on 36 respondents from Bank Banten employees. The result showed that the level of turnover intention of employees is quite high. It can be seen from the two items on the questionnaire statement that is frequently thought to leave the company immediately and look for another job. Which is this statement item represents the indicator of turnover intention by Mobley et al. (1978). So from the two items of statements having a high score, it can be concluded that the turnover intention level of employee's Bank Banten is quite high.

On the other hand, the level of organizational commitment, job satisfaction, and work motivation are relatively weak. It is seen from the low score for the sense of belonging to the company, the salary and award aspects, company policies, and he opportunity to develop. So, it is crucial for Bank Banten to start paying attention for things that need to be improved to reduce turnover intention level. Which this study will be seen the effect of job satisfaction and work motivation on turnover intention. It's important to be done because Banten Bank was only established in 2016, so Bank banten must to make a massive expansion assisted by their employees to develop innovative products and facilities.

\section{LITERATURE STUDY}

\section{Job satisfaction}

According to Dadang (2013) job satisfaction is an emotional state that is pleasant or unpleasant to work. Richard et al. (2012) states that job satisfaction is related to a person's attitude or feelings about the job, salary, opportunity, promotion or education, supervision, co-workers, and others. From the explanation of some of these experts regarding job satisfaction, it can be concluded that job satisfaction is an expression of the attitude of the workers towards work, compensation and promotion, and work environment.

\section{Work motivation}

According to Mangkunegara (2010) motivation is formed from employee attitudes in dealing with work situations on the company. Usman (2006) suggests that motivation is a psychological process that encourages people to do something, so that it can from inside and outside of a person. From the explanation of some of these experts regarding work motivation, it can be concluded that work motivation is the encouragement for someone to work, so that it becomes the strength for someone to get their goals.

\section{Organizational Commitment}

Robbins and Judge (2008) stated the organizational commitment is the degree to which an employee is sided with an organization to maintain their affiliation in the organization. Meanwhile, Meyer and Allen (1993) in Salleh et al. (2016) suggest that organizational commitment is a condition where individuals consider the compatibility of their personal values and goals with the values and goals of the organization, then the extent of their desire to maintain membership in the organization. From the explanation of some of these experts regarding organizational commitment, it can be concluded that organizational commitment is an attitude that shows loyalty, confidence, interest and meaning of an organization for someone

\section{Turnover Intention}

Putri and Suana (2016) stated the turnover intention can be interpreted as an employee's intention to move from an organization or leave the organization, either dismissal or resignation. According to Zeffane (1994) in Kessler (2014) turnover intention is the tendency intention of individuals who have the desire to quit their work. From the definition of these experts, it can be concluded that turnover intentions is the desire to move from an organization, but not yet to the realization stage. 


\section{International Advanced Research Journal in Science, Engineering and Technology}

Vol. 6, Issue 5, May 2019

\section{PREVIOUS RESEARCH}

The results of the research by Youcef et al. (2016) shows that organizational commitment can mediate the effect of job satisfaction on turnover intention. On the other hand, the results of Youcef et al. (2016) and Huan et al. (2017) present that job satisfaction has a positive effect on organizational commitment. In line with Azeem (2010), Rahman et al (2014), and Othman et al. (2014) which also stated that there is a positive influence between job satisfaction and organizational commitment.

Youcef et al. (2016) and Huan et al. (2017) also shows that job satisfaction has a negative effect on turnover intention. In line with the research of Kreitner and Knicki (2010), Chang Jou et al. (2012), Cho et al. (2012), Yun Lu (2012), and Hou su et al. (2016) which also stated that job satisfaction has a negative effect on turnover intention. Besides that, according to Masydzulhak et al. (2016) suggests job satisfaction and work motivation can encourage organizational commitment. The results of the research by Xu et al. (2014) shows that work motivation has a positive effect on organizational commitment. In line with Alimohammadi and Neyshabor (2013) and Putri (2015) research which also stated that motivation has a positive effect on organizational commitment.

The results of Rumlall's research (2011) show that organizational commitment can mediate the effect of work motivation on turnover intention. In addition, the results of the research by Sajjad and Ghazanfar (2013) shows that work motivation has a negative effect on turnover intention. In line with the study of Bloch (2004) which also shows that there is a negative influence between work motivation and turnover intention. Furthermore, the research of Youcef et al. (2016) and Huan et al. (2017) shows that organizational commitment has a negative effect on turnover intention. In line with the research of Ghost et al. (2011), Yücel (2012), and Cho et al. (2012) which states that there is a negative influence between organizational commitment to turnover intention.

\section{HYPOTHESIS}

Based on the above theories then be made framework which will then be put in the form of hypotheses. The hypothesis used in this study is:

\section{Relationship between Job Satisfaction and Organizational Commitment}

More aspects in accordance with the individual's desire, the higher the level of job satisfaction, and otherwise if the less desire can be fulfilled, the lower the level of job satisfaction. Youcef et al. (2016) shows that job satisfaction has a positive effect on organizational commitment. In line with the research of Huan et al. (2017), Azeem (2010), Rahman et al. (2014), and Othman et al. (2014) which shows a positive influence between job satisfaction and organizational commitment. Thus the hypothesis can be taken that job satisfaction has a positive effect on organizational commitment. This illustrates the higher level of employee job satisfaction, the higher the organizational commitment of the employee. Similarly, if the lower employee job satisfaction, then the lower the organizational commitment of employees.

H1: Job satisfaction has a positive effect on organizational commitment.

\section{Relationship between Work Motivation and Organizational Commitment}

Employees who are highly motivated will enjoy the work provided by the company, so that employees have loyalty and commitment to the company where the employee works. Masydzulhak et al. (2016) suggests motivation and job satisfaction can encourage organizational commitment. In accordance with the research of Alimohammadi and Neyshabor (2013) which shows that work motivation has a significant positive impact on organizational commitment. In line with the research of $\mathrm{Xu}$, et al. (2014) which also shows a positive influence between work motivation and organizational commitment. Thus the hypothesis can be taken that work motivation has a positive effect on organizational commitment. This shows that the higher the employee's work motivation, the higher the organizational commitment. Similarly, if the employee's work motivation is lower, the lower the employee's organizational commitment.

H2: Work motivation has a positive effect on organizational commitment.

\section{Relationship between Job Satisfaction and Turnover Intention}

Job satisfaction will encourage employees to feel comfortable in the company. In addition, employees will also be enjoy to be part of the company. If the desires of employees are fulfilled, it will reduce turnover intention level. However, if job satisfaction is not achieved, then it can be a reason for someone to leave their job. The result of the research by Kreitner and Knicki (2010) shows that job satisfaction has a negative effect on tuning intention. Thus the hypothesis can be taken that job satisfaction has a negative effect on turnover intention. This shows that the higher level of employee satisfaction with the organization, the lower level of turnover intention in the organization, and similarly if employee satisfaction is low, the turnover intention level will be higher.

H3: Job satisfaction has a negative effect on turnover intention 


\section{International Advanced Research Journal in Science, Engineering and Technology}

Vol. 6, Issue 5, May 2019

\section{Relationship between Work Motivation and Turnover Intention}

Work motivation is needed by employees to work, because if an employee has motivation then they will be more eager to carry out their work. Besides that it will also have an impact on decreasing the desire of employees to leave their jobs. In accordance with the result of research by Sajjad and Ghazanfar (2013) shows that there is a negative influence between work motivation and turnover intention. In line with the study of Bloch (2004) which also shows the negative influence between work motivation and turnover intention. Thus the hypothesis can be taken that work motivation has a negative effect on turnover intention. This illustrates that the higher work motivation will reduce the turnover intention level, and conversely the lower work motivation will increase turnover intention level.

H4: Work motivation has a negative effect on turnover intention

\section{Relationship between Organizational Commitments and Turnover Intention}

If employee has a high level of organizational commitment then employees will feel an emotional attachment to the company and assume that moving from one company to another is a wrong decision. Employees who have high organizational commitment would not think to leave their company, they have the desire to spend the rest of their career in that company. High turnover intention in one company will give negative impact on the company by creating unstable working condition and increase the cost of recruiting new employee (Silaban and Syah, 2018). Research of Youcef et al. (2016) shows that organizational commitment has a negative effect on turnover intention. In line with the research of Huan et al. (2017), Ghost et al. (2011), Yucel (2012) and Cho et al. (2012) which also shows a negative influence between organizational commitment to turnover intention. Thus the hypothesis can be taken that organizational commitment has a negative effect on turnover intention. This illustrates that the higher the organizational commitment, the lower the level of turnover intention. Conversely, the lower the organizational commitment, the higher the turnover intention.

H5: Organizational commitment has a negative effect on turnover intention

From the description above, we can describe the research model as follows:

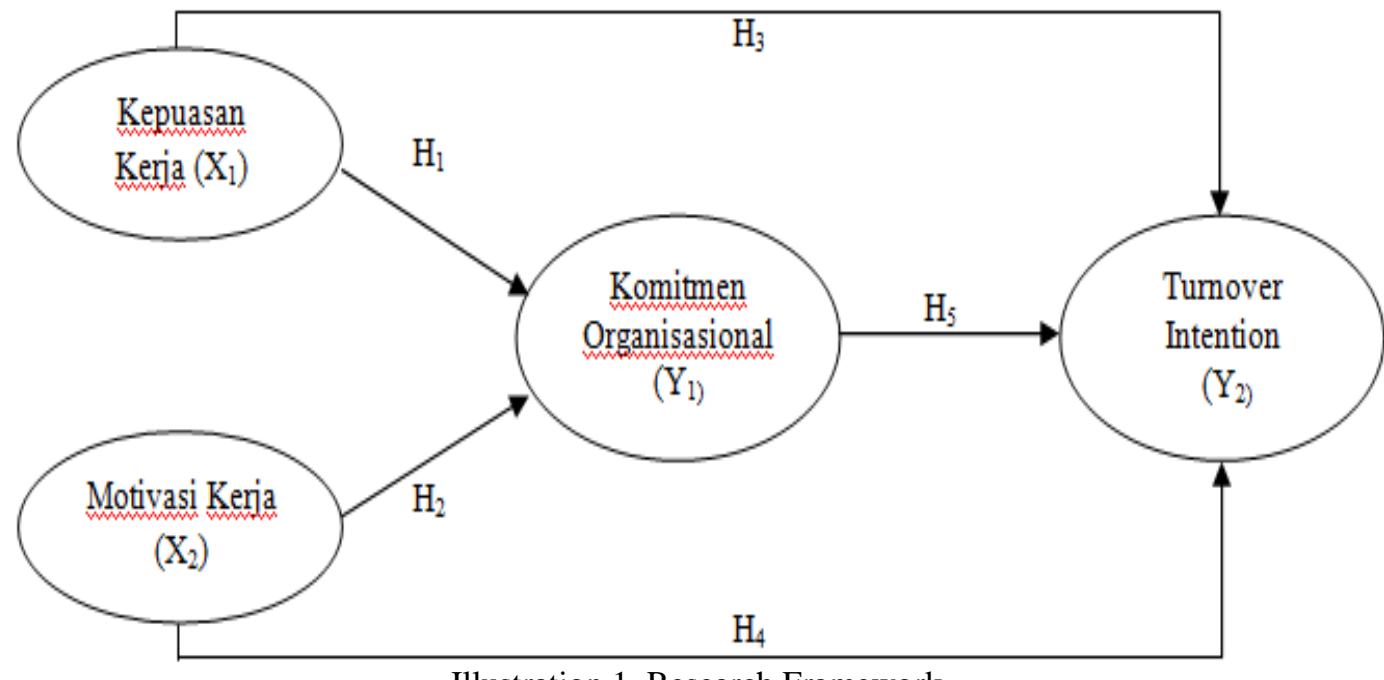

Illustration 1. Research Framework

\section{RESEARCH METHODOLOGY}

In measurements method of this study, researchers used a Likert scale of measurement through method used to measure attitudes, opinions, thoughts of a person or group of social phenomenon. On a Likert scale, methods employed using five alternative answers. The population in this research is PT. Bank BPD Banten, Tbk Serang KPO. Measurement of samples of population used references tables that developed by experts, one of which is according to Hair et al. (1998), that the number of samples $=\mathrm{n} \times 5$. The sample ini this research is employees who have worked for more than 2 years. The questionnaire will be distributed as: 39 x $5=195$ respondents. To test the hypothesis proposed in this study, analysis technique used is SEM (Structural Equation Modeling) operated through the Lisrel program.

According to Weiss et al. (1967) there are three dimensions in measuring employee job satisfaction. There are the intrinsic dimensions (activity, independence, job variation, social status, moral value, security, social service, authority, ability use, responsibility, creativity, and achievement), extrinsic dimensions ( supervision, commitment of superiors, company policies, compensation, opportunities for growth and recognition), and general dimensions (conditions of work and co-workers). Furthermore, according to McClelland (1974) work motivation can be measured in three 


\section{International Advanced Research Journal in Science, Engineering and Technology}

Vol. 6, Issue 5, May 2019

dimensions. There are need for achievement, affiliation, and power. But in this study the dimensions of need for power are not used because its has been represented by indicators of authority in the intrinsic dimension of job satisfaction. On the other hand, according to Meyer, Allen, and Smith (1993) organizational commitment can be measured In three dimensions, there are affective commitment (emotional attachment), continuous commitment (losses when they leave the company and have yet find a job), and normative commitment (committed awareness). The last, according to Mobley (1978) turnover intention can be measured by three measures, there are often think to leave the company, often looking for new jobs, and as soon as possible leave the company.

\section{RESULTS AND DISCUSSION}

Prior to the research, researchers conducted a pretest with two events ways such as validity and reliability test. In the variable job satisfaction there are 20 statements with dimension of intrinsic, extrinsic, and general. The results of pretest on intrinsic dimension with value of $\mathrm{KMO}=0.727$, the results of the pretest on extrinsic dimension with value of $\mathrm{KMO}=0.752$, and the results of the pretest on the general dimension with a value of $\mathrm{KMO}=0.531$. Furthermore, in the work motivation variable 6 statements with dimension of need for achievement and need for affiliation. The results of pretest on need for achievement dimension with value of $\mathrm{KMO}=0.583$ and the results of the pretest on the need for affiliation dimensions show the value of $\mathrm{KMO}=0.681$. Furthermore, in the organizational commitment variable there are 10 statements with dimension of affective, continuous, and normative. The results of the pretest on the affective dimension showed the value of $\mathrm{KMO}=0.705$, the results of the pretest on the continuous dimension showed the value of $\mathrm{KMO}=0.635$, the results of the pretest on the normative dimension showed the value of $\mathrm{KMO}=0.641$. The last, the result of pretest on turnover intention variable showed the value of $\mathrm{KMO}=0.668$. Because the minimum acceptable KMO value which must be $>0.5$, then all statements are valid and can be used. The results showed that value construct pretest reliability of all indicators have qualified with good reliability. After the research was conducted, the result in which value of Chi Square / Degree of Freedom $=29$, RMSEA $=0.054$ (good fit), ECVI $=0.50$, ECVI Saturated $=$ 0.57 (good fit), AIC Model $=97.69$ compared to the AIC Saturated $=1100.00$ and AIC Independence $=1879.82$. The model is slightly smaller than the AIC Independence and the difference is much greater than the AIC independence, then a small value indicates a good fit. CAIC Model $=208.79$ far from the Saturated CAIC $=345.01$, and also further from CAIC Independence $=1922.55$, then a smaller value indicates the good match. NFI $=0.98(>0.90)$ indicates good fit. Critical N $(\mathrm{CN})=219.42(>200)$ indicates good fit. Finally, the GFI value $=0.96(>0.90)$ indicates good fit. Furthermore, this study produced a T-value diagram as shown in Figure 2.

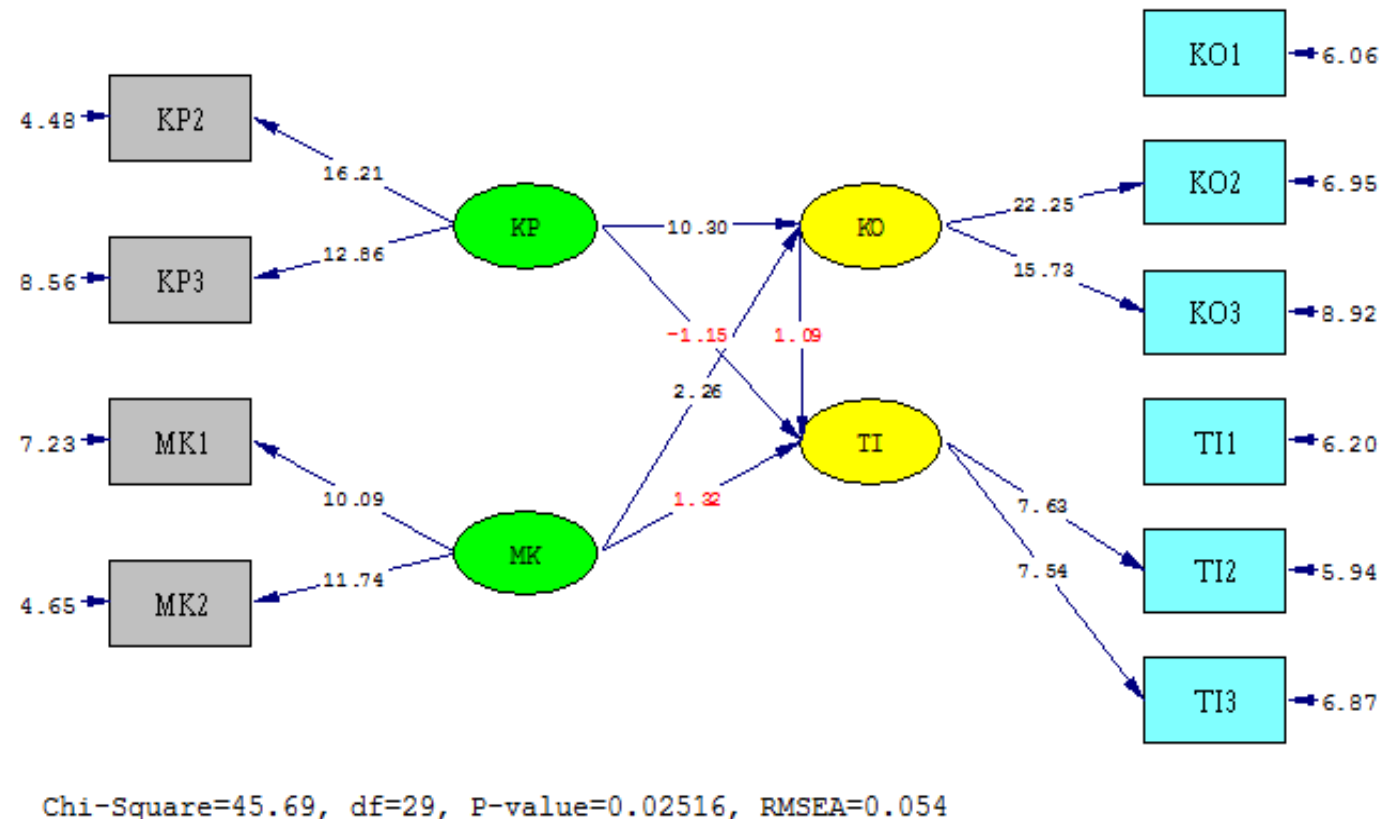

Figure 3. Diagram T-Value Path 


\section{International Advanced Research Journal in Science, Engineering and Technology}

Vol. 6, Issue 5, May 2019

In this study, there are five hypotheses that are tested and based on the results of the test obtained the results of hypothesis test is:

Table 2. The Result of Hypothesis Test

\begin{tabular}{|c|l|c|l|}
\hline Hypothesis & \multicolumn{1}{|c|}{ Hypothesis Statement } & T-value & \multicolumn{1}{|c|}{ Description } \\
\hline $\mathrm{H}_{1}$ & $\begin{array}{l}\text { Job Satisfaction has a positive effect on } \\
\text { Organizational Commitment }\end{array}$ & 10.30 & $\begin{array}{l}\text { Data support the } \\
\text { hypothesis }\end{array}$ \\
\hline $\mathrm{H}_{2}$ & $\begin{array}{l}\text { Work Motivation has a positive effect on } \\
\text { Organizational Commitment }\end{array}$ & 2.26 & $\begin{array}{l}\text { Data support the } \\
\text { hypothesis }\end{array}$ \\
\hline $\mathrm{H}_{3}$ & $\begin{array}{l}\text { Job Satisfaction has a negative effect on } \\
\text { Turnover Intention }\end{array}$ & -1.15 & $\begin{array}{l}\text { Data does not support } \\
\text { the hypothesis }\end{array}$ \\
\hline $\mathrm{H}_{4}$ & $\begin{array}{l}\text { Work Motivation has a negative effect on } \\
\text { Turnover Intention }\end{array}$ & 1.32 & $\begin{array}{l}\text { Data does not support } \\
\text { the hypothesis }\end{array}$ \\
\hline $\mathrm{H}_{5}$ & $\begin{array}{l}\text { Organizational Commitment has a negative } \\
\text { effect on Turnover Intention }\end{array}$ & 1.09 & $\begin{array}{l}\text { Data does not support } \\
\text { the hypothesis }\end{array}$ \\
\hline
\end{tabular}

In the first test results (H1), it was found that the results of the analysis support the hypothesis H1, namely job satisfaction has a positive effect on organizational commitment with t-value 10.30. This study supports research from Youcef et al. (2016) which showed the job satisfaction has a positive effect to commitment between organisation. This shows that the job satisfaction of employees' Bank Banten has effects to individual's organizational commitment. So it can be concluded that the higher job satisfaction, the higher the organizational commitment to the company. In the second test results $(\mathrm{H} 2)$, it was found that the results of the analysis support the hypothesis $\mathrm{H} 2$, namely work motivation has a positive effect on organizational commitment with t-value 10.30. This study supports research from Alimohammadi Neyshabor (2013) which also shows that there is a positive influence between work motivation and organizational commitment. This shows that the work motivation of employees of Bank Banten has effects to individuals' organizational commitment. o that it can be concluded that the higher employee's work motivation, the higher organizational commitment to the company

In the third test result (H3), it was found that the results of the analysis did not support the hypothesis $\mathrm{H} 3$, namely job satisfaction has not effect on turnover intention with t-value -1.15 which was lower than critical value $(<1.96)$. The results of this study does not support the results of research by Youcef et al. (2016) which showed that the job satisfaction has negative effect on turnover intention, but this result support the research from Wang (2016) which show that the job satisfaction has no effect on turnover intention. These results prove that there are still satisfied employees at Bank Banten but never close the possibility of leaving the company and looking for other jobs. Conversely, dissatisfaction employees at Bank Banten also did not directly to leave their jobs. This is because the employees still need work even though there are some aspects that they are not satisfied, its because more difficulty to find a better new job. So that the high or low job satisfaction level does not influence on turnover intention.

In the fourth test result (H4), it was found that the results of the analysis did not support the hypothesis $\mathrm{H} 4$, namely work motivation had no effect on turnover intention with t-value 1.32 which was lower than critical value $(<1.96)$. The results of this study does not support the results of research by Sajjad and Ghazanfar (2013) which showed that the work motivation has negative effects on turnover intention, but this result support the research from Wardhani (2000) which showed that the job satisfaction does not affect on turnover intention. The results of this study indicate that high work motivation does not necessarily reduce turnover intentions level. The employee who have high motivation will be opstimist to promoted because they are considered capable of completed their duties. Thus they decided to stay with the company. However, they also ever close the possibility of leaving the company if there are companies that can provide better benefits. In addition, interpersonal relationships with co-workers are considered by employees to leave the company. So that the high and low motivation of work does not affect turnover intention.

In the fifth test result (H5), it was found that the results of the analysis did not support the hypothesis H5, namely organizational commitment had no effect on turnover intention with t-value 1.09 which was lower than critical value $(<1.96)$. The results of this study does not support the research from Youcef et al. (2016) which showed the organizational commitment has negative effect on turnover intention, but in line with Tett and Mayer (1993). their study also stated that the organizational commitment does not have a strong influence on the withdrawal of employees. This is due to several empirical reasons from Bank Banten employee, they feel proud to be part of Bank Banten because the Banten Bank is a bank which under the auspices of BUMD. In addition, from the background of respondents dominated by men, age range 41-45 years and work period 8-9 years. This is also a consideration for employees if they leave the company. So that the high or low organizational commitment does not affect turnover intention. 


\section{International Advanced Research Journal in Science, Engineering and Technology}

Vol. 6, Issue 5, May 2019

Finally, the results of this study showed that the organizational commitment can not mediate the effect of job satisfaction on turnover intention and organizational commitment nor can mediate the effect of work motivation on turnover intention. This is indicated that the job satisfaction and work motivation that does not affect either directly or indirectly on turnover intention. This is because organizational commitment has a measure to determine the continuity of employee's relation with the company, it's shown by continuous commitment dimension. The results of the employee's statement of the item statement from the continuous dimension can be an illustration of turnover intention level, so that the high or low job satisfaction and work motivation does not effect on turnover intention.

\section{MANAGERIAL IMPLICATIONS}

Based on the results of testing of job satisfaction and work motivation on turnover intention through organizational commitment, there are several things that can be used as reference for PT. Bank BPD Banten Serang KPO, it is increase employee's participation to decision making, develop a fair and appropriate compensation system, formulating employee's need and expectations into organizational goals, create the leadership behaviors that are oriented to relationships and tasks, improve employee's clarity in the organization, create the building images, understand the character and personality of employees, created a comfortable and peaceful work climate, provide rewards for outstanding employees, make an appointment schedule, give a promotion at least 3-5 years of work period, certifying performance and employee loyalty every 3 years of work period, giving employees the opportunity to convey all their complaints, hopes, and aspirations to the.

\section{CONCLUSIONS AND RECOMMENDATIONS}

\section{Conclusion}

Based on the results of the research and analysis, it can be concluded that the job satisfaction has a positive and significant effect on organizational commitment. These results indicate that the higher job satisfaction, the higher organizational commitment. Thus, job satisfaction has a role in organizational commitment of employee in PT. Bank BPD Banten, Tbk Serang KPO. The second result of the study is work motivation has a positive and significant effect on organizational commitment. This result show that the higher work motivation, the higher the organizational commitment. In other words, work motivation has a role in organizational commitment of employee in PT. Bank BPD Banten, Tbk Serang KPO. The result of the third study is that job satisfaction has no effect on turnover intention. These results indicate the high or low job satisfaction level does not affect on turnover intention. This is because the employees in PT. BPD Banten Bank which has satisfaction never close the possibility of leaving the company if there are better job opportunities. Likewise, employees who have dissatisfaction does not immediately decide to leave the company because of many considerations and worries of loss if they leave the company. The result of the fourth study is work motivation has no effect on turnover intention. These results indicate that the level of work motivation does not affect on turnover intention. This is because employees who have high work motivation optimism that they have ability to get a better job. However, this is also considered because its difficult to finding a new job. In addition, employees feel they have a good personal relationship with their co-workers so that it is also considered by employees if they leave the company. The fifth research result is organizational commitment does not influence on turnover intention. The results of this study indicate high or low organizational commitment level does not affect on turnover intention. This is because the respondent's background is a consideration for them if they leave the company. Finally, the results of this study are that organizational commitment cannot mediate the effect of job satisfaction on turnover intention and organizational commitment nor can it mediate the effect of work motivation on turnover intention. This is due to showing job satisfaction and work motivation does not affect either directly or indirectly on turnover intention.

\section{Suggestion}

Based on the conclusions and limitations of the research that has been described, the researcher hope the results of this study can be used to provide optimal benefits for the object of subsequent research and can be a comparison material in other studies. Further research is expected to develop and be further expanded by completing the research object, so that it can enrich and deepen theories about job satisfaction, work motivation, organizational commitment, and turnover intention.

\section{Research Limitations}

The limitations in this study are limited number of respondents of 195 and variable number of four variables as well as number of analysis led to study could not dig more deeply about other factors that affect turnover intention. In this study using a questionnaire to get the data, but there are also some answers to the questionnaire statement is not accordance with the actual situation. In addition, the results of this study only can be used in organizations that have the same characteristics as PT. Bank BPD Banten, Tbk. 


\title{
International Advanced Research Journal in Science, Engineering and Technology
}

\author{
Vol. 6, Issue 5, May 2019
}

\section{REFERENCES}

[1]. Azeem. (2010). Job Satisfaction and Organizational Commitment. Journal Psychology.

[2]. Bloch Bakhsh(2004). Effects of Job Satisfaction on Employees Motivation \& Turnover Intentions. Journal of Managerial Sciences. Vol II. No 1

[3]. Chao, Ming - Che., Rong - Chang Jou, Cing - Chu Liao. \& Chung - Wei Kuo. (2015). Workplace Stress, Job Satisfaction, Job Performance and Turnover Intention of Health Care Workers in Rural Taiwan. Asia Pacific Journal of Public Health. Vol. 27. No.2.

[4]. Cho, V. and X. Huang (2012). Professional Commitment, Organizational Commitment, and The Intention to Leave for Professional Advancement. Information Technology \& People.

[5]. Daft, Richard L. (2012). Manajemen, Edisi Kelima Jilid Satu. Jakarta: Erlangga.

[6]. Hair Anderson and Tatham Black. (1998). Multivariate Data Analysis. USA: Prentice Hall.

[7]. Kessler, L. L. (2014). the Effect of Job Satisfaction on It Employees Turnover Intention, 1028-1038.

[8]. Kreitner, Kinicki. 2010. Organizational Behavior. New York: McGraw-Hill.

[9]. Mc Clelland D. (1973). Human Motivation. USA: Scott Foresman and Co.

[10]. Meyer, J.P and N.J Allen. (1993). A three-component conceptualization of organizational commitment. Human Resource Management.

[11]. Mobley, W. H., Grieth, R. W., Hand, H. H. and Meglino, B. M. (1979). Review and conceptual analysis of the employee turnover process. Psychological Bulletin..

[12]. Nasyira. M. N, Othman. M, And Ghazali. H. (2014). Predictors Of Intention To Stay For Employees Of Causal Dining Restaurant In Klang Valley Area. International Food Research Journal. Vol. 21

[13]. Sajjad, A., Ghazanfar, H., Ramsan, M.( 2013). Impact Of Motivation On Employee Turnover In Telecom Sector Of Pakistan. Journal Of Business Studies Quarterly. Vol 5. No 1.

[14]. Salleh, S. M., Zahari, A. S. M., Said, N. S. M., \& Ali, S. R. O. (2016). The Influence of Work Motivation on Organizational Commitment in the Workplace. Journal of Applied Environmental and Biological Sciences, 6(58), 139-143.

[15]. Silaban, N., Yanuar and Tantri R. Syah. (2018). The Influence of Compensation and Organizational Commitment on Employees' Turnover Intention. IOSR Journal of Business and Management, 20(3), 1-6

[16]. Xu S, Choi Y,Qin LV. (2014). Subject Well Being, Work Motivation, Organizational Commitment. Journal of Tourism Research and Hospitality.

[17]. Youcef, S., Ahmed, S. S., \& Ahmed, B. (2016). The Impact of Job Satisfaction on Turnover Intention by the Existence of Organizational Commitment, and Intent to Stay as Intermediates Variables Using approach PLS in Sample Worker Department of Transport Saida. Management, 6(6), 198-202.

[18]. Yücel, Ilham. (2012). Examining the Relationships among Job Satisfaction, Organizational Commitment, and Turnover Intention: An Empirical Study. International Journal of Business and Management. Vol. 7. No. 20 